\title{
Erratum to: Guidelines for the use and interpretation of diagnostic methods in adult food allergy
}

Donatella Macchia ${ }^{1}$, Giovanni Melioli ${ }^{2}$, Valerio Pravettoni ${ }^{3}$, Eleonora Nucera ${ }^{4}$, Marta Piantanida ${ }^{3}$,

Marco Caminati ${ }^{*}$, Corrado Campochiaro ${ }^{6}$, Mona-Rita Yacoub ${ }^{6}$, Domenico Schiavino ${ }^{4}$, Roberto Paganelli ${ }^{7}$, Mario Di Gioacchino ${ }^{8}$ and On behalf of the Food Allergy Study Group (ATI) of the Italian Society of Allergy, Asthma and Clinical Immunology (SIAAIC)

\section{Erratum to: Clin Mol Allergy (2015) 13:27}

\section{DOI 10.1186/s12948-015-0033-9}

After the publication of this work [1] some errors were noticed in Figure 1. The corrected figure is provided below. The original conclusions will not be affected by this Erratum. 


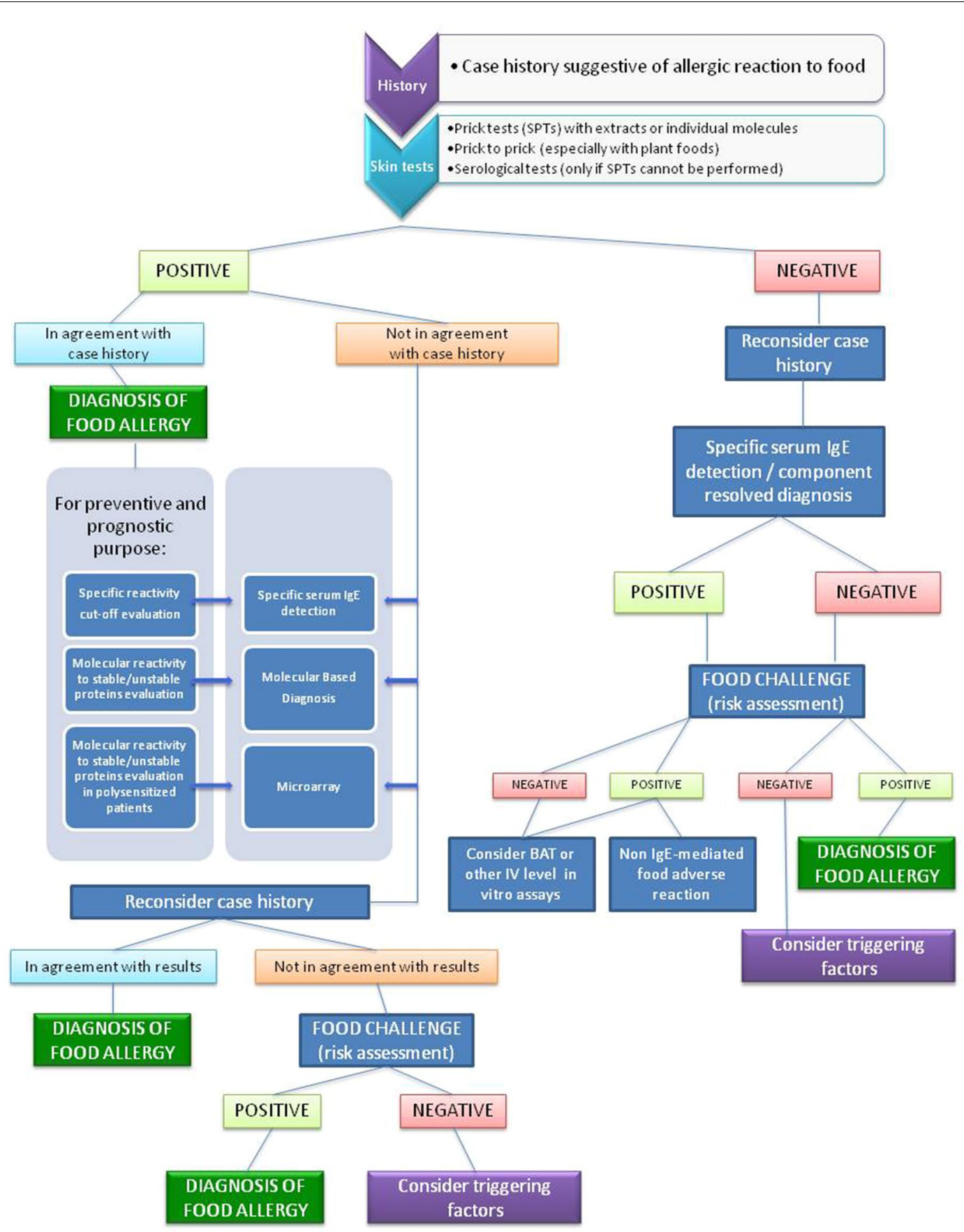

Fig. 1 Flow chart for the diagnosis of food allergy 


\section{Author details}

1 SS Allergology and Clinical Immunology, S. Giovanni di Dio Hospital, Florence, Italy. ${ }^{2}$ Respiratory Diseases and Allergy, University of Genoa, IRCCS AOU S. Martino-IST, Genoa, Italy. ${ }^{3}$ Allergology and Immunology Unit, IRCCS Ca' Granda, Osp. Maggiore Policlinico, Milan, Italy. ${ }^{4}$ Servizio di Allergologia, Policlinico Gemelli, Rome, Italy. ${ }^{5}$ Allergy Unit, Verona University and General Hospital, Verona, Italy. ${ }^{6}$ Department of Allergy and Clinical Immunology, IRCCS San Raffaele Hospital, Milan, Italy. ${ }^{7}$ Department of Medicine and Science of Ageing, G. d'Annunzio University, Chieti, Italy. ${ }^{8}$ Unit of Allergy and Immunotoxicology, CeSi, "G. d'Annunzio" University Foundation, Chieti, Italy.

The online version of the original article can be found under doi:10.1186/s12948-015-0033-9.
Received: 3 December 2015 Accepted: 3 December 2015

Published online: 21 December 2015

\section{Reference}

1. Macchia D, Melioli G, Pravettoni V, Nucera E, Piantanida M, Caminati M, et al. Guidelines for the use and interpretation of diagnostic methods in adult food allergy. Clin Mol Allergy. 2015;13:27.
Submit your next manuscript to BioMed Central and we will help you at every step:

- We accept pre-submission inquiries

- Our selector tool helps you to find the most relevant journal

- We provide round the clock customer support

- Convenient online submission

- Thorough peer review

- Inclusion in PubMed and all major indexing services

- Maximum visibility for your research

Submit your manuscript at www.biomedcentral.com/submit
() BioMed Central 